\title{
CRIMINAL LAW: THE DEFENDANT'S “CAPACITY”- TOWARD A REFORMED TEST OF CRIMINAL INSANITY
}

Two recent decisions manifest growing dissatisfaction with the M'Naghten and Durham tests of criminal insanity. A concurring opinion in one instance and a majority opinion in the other suggest that criminal responsibility should depend on the "capacity" of the defendant to avoid the criminal act.

In a well-considered concurring opinion in the case of Blocker v. United States, Judge Burger, joined by two other members of the Court of Appeals for the District of Columbia, ${ }^{2}$ expressed disapproval of the "disease-product" test adopted by that court in the controversial case of Durham v. United States. ${ }^{3}$ Judge Burger reviewed the inadequacies which he felt had become apparent in the Durham formula and set forth the following test as an alternative:

The defendant is not to be found guilty as charged unless it is established beyond a reasonable doubt that when he committed the act, first, that he understood and appreciated that the act was a violation of law, and second, that he had the capacity to exercise his will and to choose not to do it. If, because of some abnormal mental condition, either of these elements is lacking, he cannot be found guilty. ${ }^{4}$

Shortly after the Blocker decision, the Court of Appeals for the Third Circuit in United States v. Currens ${ }^{5}$ held that a charge given in terms of the $M^{\prime} N a g h t e n$ rule ${ }^{6}$ was prejudicial error. In granting a new trial, the court suggested the following charge:

${ }^{1} 288$ F.2d 853, 857 (D.C. Cir. 1965) (concurring opinion).

Judge Burger did not speak to the issues discussed in the majority opinion, which called for reversal of a first degree murder conviction on the ground that the district court had erroneously instructed the jury by not clearly placing the burden of proving sanity on the prosecution. Concurring in the result only, Judge Burger presented a lengthy and well-documented discourse on rules of criminal insanity in general and the Durham rule in particular.

' Chief Judge Miller and Circuit Judge Bastian joined in the views expressed in this opinion as to the need for a change in the standard of criminal responsibility. Id. at 873.

${ }_{214}$ F.2d 862 (D.C. Cir. 1954). The essence of the Durham holding was that a person could not be convicted if his criminal act was the product of a diseased or defective mental condition. Id. at 875 .

4288 F.2. at 871 .

29o F.2d 75r (3d Cir. 196r).

- "[T]o establish a defense on the ground of insanity, it must be clearly proved that, 
The jury must be satisfied that at the time of committing the prohibited act the defendant, as a result of mental disease or defect, lacked substantial capacity to conform his conduct to the requirements of the law which he is alleged to have violated. ${ }^{7}$

Although one of these opinions represents a departure from Durham and the other from $M^{\prime}$ Naghten, the proposed new tests of criminal insanity are quite similar. Each would require both cognitive and volitional powers on the part of the defendant as necessary elements of criminal responsibility, and each is phrased in terms of the defendant's "capacity."

The $M$ 'Naghten rule is still law in all but a few jurisdictions, ${ }^{8}$ but has long been under sharp attack." A strict "knowledge-of-right-andwrong" test does not give a proper indication of criminal intent, since an act can be committed as a result of mental disease even though its perpetrator is fully aware of its unlawful and immoral nature. ${ }^{10}$ It has

at the time of the committing of the act, the party accused was labouring under such a defect of reason, from disease of the mind, as not to know the nature and quality of the act he was doing; or, if he did know it, that he did not know he was doing what was wrong." M'Naghten's Case, 10 Cl. \& Fin. 200, 210, 8 Eng. Rep. 718, 722 (H.L. 1843).

It should be noted that there are actually two branches to the M'Naghten rule: the accused is not criminally responsible where he does not know the nature and quality of the act, as well as where he does not know right from wrong with respect to the act.

${ }^{3} 290$ F.2d at 774 .

${ }^{8}$ The only jurisdictions to depart froin M'Naghten by judicial decision have been the District of Columbia in Durham v. United States, 214 F.2d 862 (1954), and the Third Circuit in United States v. Currens, 290 F.2d 751 (1961). New Hampshire never adopted the M'Naghten rule. See State v. Jones, 50 N.H. 369 (1871); State v. Pike, 49 N.H. 399 (1869).

${ }^{\circ}$ For criticisms of the M'Naghten rule proferred by legal and psychiatric authorities, see Cardozo, What Medicine Can Do for Law, in Law and Literature and OTHER Essays aNd AdDRESSES 70, 108 (1931); COMMITTEe on PSYCHIATRY AND THE LAW OF the Group for the Advancement of Psychiatry, Report No. 26, Criminal Responsibility and Psychiatric Expert Testimony (1954); Glueck, Mental Disorder and the Criminal LaW 169-70 (1927); Royal Commission on Capital PUNISHMENT 1949-1953, RePoRT paras. 289-97, at 102-05 (1953); Douglas, The Durham Rule: $A$ Meeting Ground for Lawyers and Psychiatrists, 41 IowA L. REv. 485 (1956).

${ }^{10}$ The Royal Commission on Capital Punishment reported in 1953 that the "right and wrong" test has been objected to by experienced doctors for over a hundred years as ". . . based on an entirely obsolete and misleading conception of the nature of insanity, since insanity does not only, or primarily, affect the cognitive or intellectual faculties, but affects the whole personality of the patient, including both the will and the emotions. An insane person may therefore often know the nature and quality of his act 
also been pointed out that the $M$ 'Naghten rule does not fully utilize the techniques of modern psychiatry, inasmuch as the medical expert's testimony is required to focus upon the single all-important issue of whether the defendant knew right from wrong at the time of the act.11

The federal courts along with at least fourteen states have modified M'Naghten by adding the "irresistible impulse" rule, ${ }^{12}$ thus recognizing the volitional aspect of criminal responsibility. ${ }^{13}$ This modification serves to broaden the $M^{\prime} N$ aghten test, but still does not include persons without volitional capacity whose crimes have not been accomplished in a sudden or impulsive manner. ${ }^{14}$

and that it is wrong and forbidden by law, and yet commit it as a result of the mental disease." Report of the Royal Commission on Capital PUNishment 1949-1953, Report para. 232, at 82 (1953). See Sobeloff, From M'Naghten to Durham, and Beyord-A Discussion of Insanity ard the Criminal Law, 15 MD. L. REv. 93, 95 (1955); Woolf, Criminal Responsibility and Insanity: Past-Present-Future, 27 TENN. L. REv. 389,39 r-92 (rg60).

Prof. Hall is practically alone in his view that a test based solely on the defendant's powers of reason is sufficient for determining criminal imsanity. See Hall, Mental Disease and Crininal Responsibility-M'Naghten Versus Durham and the American Law Institute's Tentative Draft, 33 IND. L.J. $212,213-14$ (1958).

12 "The vast absurdity of the application of the M'Naghten Rules in order to determine the sanity or insanity, the mental health or lack of it, of the defendant by securing the answer to a single question: Did the defendant know the difference between right and wrong, appears clearly when one surveys the array of symtomatology which the skilled psychiatrist employs in determining the mental condition of an individual." United States v. Currens, 290 F.2d 751, 766-67 (3d Cir. 196I).

${ }^{23}$ The irresistible impulse rule was originally stated in an enlightened opinion by Justice Somerville of the Alabama Supreme Court : "[The defendant] may . . . not be legally responsible ... if, by reason of the duress of ... inental disease, he had so far lost the power to choose between the right and wrong, and to avoid doing the act in question, as that his free agency was at the time destroyed; and if, at the same time, the alleged crime was so connected with such mental disease, in the relation of cause and effect, as to have been the product of it solely." Parsons v. State, 8 I Ala. 577, 597, 2 So. $854,866(1887)$.

${ }^{23}$ Sauer v. United States, 241 F.2d 640 (9th Cir. 1957), cert. denied, 354 U.S. 940 (1957); United States v. Gundelfinger, 102 F. Supp. I77 (W.D. Pa. 1952); United States v. Smith, 5 U.S.C.M.A. 314 , I7 C.M.R. 314 (1954); Barbour v. State, 262 Ala. 297, 78 So. $2 d 328$ (1954); Korsak v. State, 202 Ark. 92 I, I54 S.W.2d 348 (1941); Arridy v. People, 103 Colo. 29, 82 P.2d 757 (1938); State v. Johnson, 40 Conn. 136 (1873); State v. Jack, 20 Del. (4 Penne.) 470, 58 Atl. 833 (1903); People v. Munroe, 15 Ill. 2 d 9r, 154 N.E.2d 225 (1958); Lykins v. State, 23 I Ind. 258 , 108 N.E.2d 270 (1952); Sharp v. Commonwealth, 308 Ky. 765, 215 S.W.2d 983 (1948); Commonwealth v. McCann, 325 Mass. 5 ro, 9 I N.E.zd 214 (1950); People v. Quimby, 134 Mich. 625, 96 N.W. 1061 (1903); State v. Narich, 92 Mont. 17, 9 P.2d 477 (1932); State v. Upton, 60 N.M. 205, 290 P.2d 440 (1955); State v. Green, 78 Utah 580,6 P.2d 177 (r93I); Thompson v. Commonwealth, I93 Va. 704, 70 S.E.2d 284 $(1952)$.

"State v. White, 58 N.M. 324, 270 P.2d 727 (1954); Model Penal Code \$ 4.01, 
Although New Hampshire never adopted the M'Naghten rule, ${ }^{10}$ it voiced a lone dissent until 1954, when the Court of Appeals for the District of Columbia reached its landmark decision in Durham v. Urited States. ${ }^{18}$ The "disease-product" approach followed in these jurisdictions corrects some shortcomings of $M^{\prime}$ Naghten by making relevant, and therefore admissible as evidence, a broad range of medical testimony, thus looking beyond the narrow question of the defendant's cognition. However, the Durham rule is far more adequate in theory than in practice. By use of the words "mental disease or defect," Durham laid down a rule of law in psychiatric terms which have no clear meaning to the average jury. ${ }^{17}$ In defining "mental disease or defect" the medical expert is likely. to usurp the jury's role as final arbiter of fact. ${ }^{18}$

comment at 157 (Tent. Draft No. 4, r955); RoYal Commission on Capital PuNISHMENT 1949-r953, REPORT para. 314, at 1 10 (1953). See United States v. Smith, supra note 12.

${ }^{15}$ The New Hampshire rule, as set forth in State v. Pike, 49 N.H. 399, 402 (1870), is that "the verdict should be 'not guilty by reason of insanity' if the [unlawful act] .... was the off-spring or-product- of mental disease. . .."

${ }^{10} 214$ F.2d 862 (D.C. Cir. 1954).

Some commentators indicate that while the New Hampshire rule and the Durham rule are identical in language, they differ in that the former is cast as a rule of evidence governing the scope of evidence to be received while the latter lays down a rule of law. See Reid, Understanding the New Hampshire Doctrine of Criminal Insanity, 69 YaLE L.J. $367,371,389-91$ (1960).

17 "The rule we adopted in 1954 is based on the premise that the critical threshold issue is whether the defendant has a 'mental disease or defect.' Our opinion did not define these terms except to say that the former is a 'condition which is considered capable of either improving or deteriorating' while the latter was fixed and subject neither to improvement nor deterioration. This merely distinguishes 'disease' from 'defect' without defining either term. Not being judicially defined, these words mean in any given case whatever the expert witnesses say they inean." Blocker v. United States, 288 F.2d 853,859 (D.C. Cir. 196r) (concurring opinion).

It is doubtful that the Durham test can be improved by a more precise definition of terms. As to the feasibility of a definitional test of criminal insanity, Professor Whitehorn of the Johns Hopkins School of Medicine wrote in a report to the Governor of Maryland:

"Psychiatrists are challenged to set forth a crystal-clear statement of what constitutes insanity. It is impossible to express this adequately in words, alone, since such diagnostic judgments involve clinical skill and experience which cannot wholly be verbalized. .... The medical profession would be baffled if asked to write into the legal code universally valid criteria for the diagnosis of the many types of psychotic illness which may seriously disturb a person's responsibility, and even if this were attempted, the diagnostic criteria would have to be rewritten from time to time, with the progress of psychiatric knowledge." Quoted in GutTMacher \& Weihofen, Psychiatry and THE LAW 419-20 (1952).

18 "And as medical witnesses time after time express directly opposite opinions in the witness-box concerning the sanity of prisoners on trial, it is not surprising that 
Furthermore, the.Durham formula gives the jury no guide as to the nature of the causal link required between the mental disease and the criminal act. ${ }^{19}$

Since 1954, writers have sought a test of criminal insanity which would provide the jury with an understandable guide and at the same time permit far-ranging medical testimony. The test most often discussed has been that proposed in the Model Penal Code: ${ }^{20}$

(I) A person is not responsible for criminal conduct if at the time of such conduct as a result of mental disease or defect he lacks substantial capacity either to appreciate the criminality of his conduct or to conform his conduct to the requirements of law.

(2) The terms 'mental disease or defect' do not include an abnormality manifested only by repeated criminal or otherwise anti-social conduct. ${ }^{21}$

The phrase "capacity ... to appreciate the criminality of his conduct" is essentially a restatement of the $M$ 'Naghten cognitive test, while the words "capacity ... to conform his conduct to the requirements of law" reflect the Durham rule's recognition of volitional and emotional criteria of criminal responsibility. However, the Durham standard measures the extent to which mental disease has caused the criminal act, while the Model Penal Code looks to the defendant's capacity to obey the law. This different approach makes the code provision far easier to apply than its Durham counterpart. The Durham rule, in its focus

the legal profession hold that the test of insanity must be such that a jury can appreciate and apply it themselves." EAST, FORENSIC PSYCHIATRY 68-69 (1927), quoted in Michael \& Wechsler, Criminal Law and Its Administration 836-37 (i940).

See Woolf, Criminal Responsibility and Insanity: Past-Present-Future, 27 TENN. L. REV. 389,397 (1960), and materials cited therein.

"The Durham rule requires that the act be a "product" of disease. However, the meaning of the word, "product," is left to the jury as a question of fact. Thus the jury can do little more than speculate as to what the word means. See Model PENAL CODE $\$ 4.01$, comment at I59 (Tent. Draft No. 4, 1955); Szasz, Psychiatry, Ethics, and the Criminal Law, 58 CoLUM. L. REv. 183, 190-91 (1958); Wechsler, The Criteria of Criminal Responsibility, 22 U. CH1. L. Rev. 367 (1955).

${ }^{20}$ Model Penal Code $\$ 4.01$ (Tent. Draft No. 4, 1955). See Note, The American Law Institute's Insanity Test, 1959 DUKE L.J. 317.

${ }^{22}$ The Model Penal Code provision is apparently acceptable in the Eighth Circuit. Dusky v. United States, 295 F.2d 743, 759 (8th Cir. 1961).

Several state courts have expressed some support for the new test. See People v. Carpenter, II IIl. 2d 60, I42 N.E.2d I I (1957); Commonwealth v. Chester, 337 Mass; 702, 150 N.E.2d 914 (1958); Kwosek v. State; 8 Wis. 2d·640; 100 N.W.2d 339, 346 ( 1960$)$ (concurring opinion).

In 1957 the Vermont legislature adopted with slight modification the standard recommended by the American-Law Institute in $\$ 4.01^{\prime}$ of the Model Penal Code. See* VT. Stat. ANN. tit. I3, $\$_{480}$ (1958). 
on "defect," "disease," and "product," hinges on words which mean little to the jury. ${ }^{22}$ The code looks to the condition of the defendant and employs a plain standard, which, even if vague, can be understood and applied by the jury without forced reliance upon expert testimony. ${ }^{23}$

Although praised for combining the approaches of the other rules of criminal insanity, the Model Penal Code's "capacity" test has been criticized as having incorporated some of their weaknesses. Critics maintain that the "capacity" test, like the M'Naghten rule, focuses on the defendant's control, which psychiatrists have long been unable to measure. $^{24}$ There is no answer to this argument except that such is the price of a test stated in terms which can be understood and independently applied by a non-expert jury. Other writers have said that the new approach may not resolve the causality problem of the Durham test, since the lack of capacity must be a "result" of mental disease. ${ }^{25}$ On the contrary, it seems that the new test lessens the problem by substituting "capacity" as the focal issue and by shortening the causal question from whether the disease caused the act to whether the disease caused a lack of capacity. Critics have understandably pointed to the vagueness. of the term "substantial capacity." Although vague, the term does provide a comprehensible standard upon which a jury can base its verdict. Such a test is hardly less precise than the "reasonable man" standard of due care or the "substantial contact" test used to determine corporate amenability to suit in a particular state.

Both the Currens decision and Judge Burger's concurrence in Blocker diverge somewhat from the Model Penal Code. The court in Currens rejected the part of the code which deals with the defendant's capacity to appreciate the criminality of his conduct. It was reasoned that this aspect of the code "would overemphasize the cognitive element of criminal responsibility and distract the jury from the crucial issues

\footnotetext{
${ }^{22}$ See nn. I7 \& Ig supra.

28 Although the Model Penal Code employs the words "mental disease or defect" as well as the word "result," these terms do not form the essence of the test. Rather, they serve merely to delimit the origin of the incapacity. The code points to the question of the defendant's "capacity" as the central issue.

${ }^{26}$ See MODEL. PENAL CODE $\$$ 4.01, appendix $c$ at 187-88 (Tent. Draft. No. 4, 1955). Woolf, supra note 17 , at $40 \mathrm{x}$.

${ }^{25}$ See Symposium, Mental Disease and Criminal Responsibility, 4 Catholic Law. 294, 307 (1958).

${ }^{20}$ See MODel Penal Code $\$ 4.0 x$, comment at 158-59 (Tent. Draft No. 4, 1955); Sobeloff, Insanity and the Criminal Law: From M'Naghten to Durham, and Beyont, 41 A.B.A.J. 793, 878 (2955).
} 
while being little more than surplusage."27 By removing this carryover from M'Naghten, the Third Circuit simplified the test without apparently changing its meaning. ${ }^{28}$ Rather than abbreviate the code test, Judge Burger in the Blocker case substitutes the words "capacity to exercise his will and to choose not to do it" for "capacity . . . to conform his conduct to the requirements of law." This substitution makes the volitional aspect of the test more specific, but necessitates retention of the phrase omitted in Currens in order to supply the cognitive element of the test. ${ }^{29}$ Thus these opinions suggest that the Model Penal Code can be improved, either by shortening it or by preserving its dual character and making it more specific.

In conclusion, the M'Naghten and Durham tests are recommended more by precedent than by experience. The "capacity" approach taken by the American Law Institute affords standards more realistic than M'Naghten and more practicable than Durham. ${ }^{30}$ These recent cases

\section{F.2d at $774, \mathrm{n} .32$.}

The court implies that a defendant who lacks substantial capacity to appreciate the criminality of his conduct is criminally insane on the ground that he lacks substantial capacity to conform his conduct to the law which he is alleged to have violated. Ibid. If the first test is "surplusage," it follows that persons who would be acquitted under it would be acquitted as well under the second test.

${ }^{28}$ Another departure from the code taken by the Third Circuit is of doubtful value. Under the Currens proposal, the defendant must lack substantial capacity to conform his conduct, not merely to "law," but to the "law which he is alleged to have violated." The increased specificity seems unwarranted, since the defendant has merely to point to his criminal act as evidence that he lacked capacity to conform to the law which he is alleged to have violated.

20 A more questionable feature of Judge Burger's opinion is that, unlike the Currins decision, it does not accept part two of the Model Penal Code provision, and apparently would bring psychopaths within the scope of the test even though they show no symptoms other than repeated anti-social conduct. If psychopaths exercise some control over their actions and are not likely to benefit from medical treatment, it seems that they should be convicted and sentenced for their crimes. See testimony of Dr. Cushard in Ragsdale v. Overholser, 28 I F.2d 943, 945 D.5 (D.C. Cir. 1960); RocHE, The Criminal Mind 257-58 (1958).

${ }^{20}$ Any change in the law will necessitate certain adjustments. The obvious danger in changing from the strict M'Naghten rule to the less demanding "substantial capacity" criteria is that offenders may be prematurely released back into society. This problem could not have arisen in the Blocker case, because Congress, in the wake of the Durkam decision, provided for the automatic commitment to a mental institution of persons acquitted in the District of Columbia by reason of insanity. D.C. CoDE ANN. $\$ 24-301$ (d) (Supp. 1958). See Note, I96I Duke L.J. 481. In the absence of statute, courts have differed as to the available procedure in the event that a person is found not guilty on grounds of insanity. See Pollard v. United States, 282 F.2d 450, 464, Order of Issuance of New Mandate, 285 F.2d 81 (6th Cir. 1960); Howard v. United States, 229 F.2d 602, 608 (sth Cir. 1956) (dissenting opinion). But see Sauer v. 
indicate possible improvements in the Model Penal Code provision. Herein lies a sound basis for the long overdue departure from the prevailing rules of criminal insanity.

United States, 241 F.2d 640, 651-52, n.32 (9th Cir, 1957). The Third Circuit in the Cutrens decision treated the problem by suggesting that in the event Currens should be acquitted, "the federal authorities should bring him and his condition to the attention of the State authorities to the end that he may not remain in a position in which he might be a danger to himself or to the public." United States v. Currens, 29o F.2d 75r, 776 ( 3 d Cir. 196r). 